\title{
PENERAPAN PENDEKATAN SAINTIFIK DENGAN MEDIA KONKRET DALAM PENINGKATAN KEMAMPUAN MEMECAHKAN MASALAH PADA MATEMATIKA TENTANG BANGUN RUANG PADA SISWA KELAS IV SDN 2 KLAPASAWIT TAHUN AJARAN 2017/2018
}

\author{
Diky Zulkarnain AS Syarif', Joharman², Rokhmaniyah³
}

1,2, 3 Universitas Sebelas Maret

diky.zoelkarnain@gmail.com

Article History

accepted 01/06/2019

approved 01/07/2019

published 01/08/2019

\begin{abstract}
The objective of this research is to improve Mathematics learning about fraction. This research is a collaborative Classroom Action Research (CAR). Subjects of the research were a teacher and 25 fourth grade students. Techniques of collecting data were observation, interview and test. Validity of data in this research was analyzed using triangulation of sources and triangulation of technique. Data were analyzed using data reduction, data display, and drawing conclusion. The result of this research show that the application of scientific approach using concrete media can improve Mathematics learning about fraction.
\end{abstract}

Keywords: problem solving ability, scientific approach, concrete media

\section{Abstrak}

Tujuan penelitian ini yaitu meningkatkan kemampuan memecahkan masalah matematika tentang bangun ruang. Penelitian ini merupakan penelitian tindakan kelas (PTK) kolaboratif. Subjek penelitian ini adalah guru dan siswa kelas IV yang berjumlah 25 siswa. Teknik pengumpulan data pada penelitian, yaitu observasi, wawancara, dan tes. Validitas data menggunakan triangulasi sumber dan triangulasi teknik. Analisis data melalui reduksi data, penyajian data, dan penarikan kesimpulan. Hasil penelitian menunjukkan bahwa penerapan pendekatan saintifik dengan media konkret dapat meningkatkan kemampuan memecahkan masalah matematika.

Kata kunci: kemampuan memecahkan masalah, pendekatan saintifik, media konkret 


\section{PENDAHULUAN}

Pendidikan di sekolah dasar, siswa masuk pada jenjang pertama tempat memperoleh pendidikan dasar yang merupakan fondasi bagi jenjang pendidikan selanjutnya. Tujuan dari pendidikan dasar yaitu memberikan bekal kemampuan dasar dalam kehidupan pribadi peserta didik pada khusunya, serta dalam anggota masyarakat, warga negara, umat manusia pada umumnya. Pendidikan dasar juga diperuntukan peserta didik untuk mengikuti pendidikan menengah. Maka, dalam pembelajaran matematika siswa harus diberikan kesem-patan untuk mengalami dan mene-mukan sendiri tentang makna dari materi yang diajarkan sehingga mudah dipahami oleh siswa.

Berdasarkan fakta-fakta di atas dapat diketahuai bahwa pembelajaran yang dilaksanakan di SDN 2 Klapasawit belum secara maksimal mengembangkan kemampuan memecahkan masalah pada siswa. Hal tersebut mengakibatkan rendahnya hasil belajar siswa dalam pembelajaran Matematika. Dari data nilai ulangan tengah semester yang diperoleh peneliti dan guru kelas IV SD N 2 Klapasawit, masih banyak siswa yang mendapatkan nilai di bawah KKM yang ditetapkan sekolah yaitu 68. Dari 25 siswa, baru 15 siswa yang telah memenuhi KKM. Jika dibuat persentase, siswa yang nilainya mencapai KKM $60 \%$, sedangkan $40 \%$ sisanya belum memenuhi KKM. Selain itu nilai rata-rata ulangan tengah semester siswa baru mencapai 67,28 sementara standar KKM dari sekolah 68. Dari data tersebut, perlu adanya suatu perbaikan untuk meningkatkan hasil belajar matematika yang berdampak pada meningkatnya kemampuan memecahkan masalah matematika siswa, serta media pembelajaran yang mampu menyampaikan materi Matematika secara lebih detail. Hal tersebut dikarenakan beberapa alasan: (1) penjelasan guru kurang diperhatikan siswa, (2) siswa hanya mempelajari materi Matematika dengan mendengarkan ceramah guru yang itu membuat siswa kurang termotivasi untuk aktif dalam pembelajaran, (3) siswa menghafal materi pada buku, (4) siswa kurang diajak untuk menemukan suatu konsep dalam pembelajaran matematika, (5) guru masih menggunakan pendekatan deduktif, yaitu pendekatan yang ditandai dengan pemaparan konsep (rumus) pada awal pembelajaran, sehingga siswa kurang menggali pengetahuannya. Ini mengakibatkan kurangnya kemampuan siswa dalam memecahkan masalah matematika.

Berdasarkan masalah di atas, maka langkah perbaikan yang mungkin dilaksanakan adalah mene-rapkan pendekatan saintifik dengan media konkret dalam pembelajaran matematika.

Pembelajaran dengan pendekatan saintifik adalah pembelajaran yang dirancang sedemikian rupa agar peserta didik secara aktif mengonstruk konsep, hukum atau prinsip melalui tahapan-tahapan mengamati (untuk mengidentifikasi atau menemukan masalah), merumuskan masalah, mengajukan atau merumuskan hipotesis, mengumpulkan data dengan berbagai teknik, menganalisis data, menarik kesimpulan dan mengomunikasikan konsep, hukum atau prinsip yang "ditemukan". (Hosnan, 2014: 34). Adapun keunggulan pendekatan saintifik adalah pembelajaran berpusat pada siswa, membentuk student self concept, siswa berpeluang melakukan penemuan hasil materi yang mereka pelajari (Daryanto, 2014:58-59).

Selanjutnya mengenai media konkret, yang juga dapat diartikan sebagai media nyata, realita, atau realia. Asyhar (2011: 54) yang menyatakan bahwa, "benda realita atau benda nyata adalah benda yang dapat dilihat, didengar, atau dialami oleh siswa sehingga memberikan pengalaman langsung kepada mere-ka". Anitah (2009: 146) menjelaskan, realia atau objek merupakan benda sebenarnya yang berbentuk utuh dapat berupa orang, binatang, rumah, dan sebagainya..

Penerapan pendekatan saintifik yang dipadukan dengan media konkret sangat sesuai diterapkan pada siswa kelas IV SD. Ditinjau dari segi karakteristik perkembangan anak, menurut Piaget (Anitah, 2009:9), anak yang berusia 9-11 tahun termasuk pada fase operasional konkret, yang memiliki karakteristik yaitu berpikir secara logis dan realistik, dan memiliki rasa ingin tahu yang tinggi, sehingga langkah- 
langkah pendekatan saintifik yang ditunjang dengan media konkret sangat cocok untuk menjadi jembatan bagi siswa untuk mengembangkan rasa ingin tahu, menemukan pengetahuan, serta mengembangkan kemampuan memecahkan masalah.

Rumusan masalah dalam penelitian ini yaitu: apakah penerapan pendekatan saintifik dengan media konkret dapat meningkatkan kemampuan memecahkan masalah matematika tentang bangun ruang pada siswa kelas IV SDN 2 Klapasawit tahun ajaran 2017/2018?

Tujuan penelitian ini adalah: untuk meningkatkan kemampuan memecahkan masalah matematika tentang bangun ruang pada siswa kelas IV SDN 2 Klapasawit tahun ajaran 2017/2018 melalui penerapan pendekatan saintifik dengan media konkret.

\section{METODE}

Penelitian ini merupakan penelitian tindakan kelas (PTK) yang dilakukan secara kolaboratif yang dilaksanakan di SDN 2 Klapasawit pada bulan November 2017 sampai April 2018. Subjek dalam penelitian ini siswa kelas IV dengan jumlah siswa 25 siswa, yang terdiri dari 12 siswa laki-laki dan 13 siswa perempuan.

Data adalah hasil catatan peneliti yang berupa fakta ataupun angka (Arikunto, 2013: 161). Pada penelitian tindakan kelas data yang diperoleh berupa data kuantitatif dan data kualitatif (Mulyasa, 2013: 68). Jenis data yang digunakan pada penelitian berupa nilai tes tertulis siswa dan proses penerapan pendekatan saintifik dengan media konkret serta kendala dan solusi.

Validasi menurut Sugiyono (2009: 363) merupakan derajad ketepatan antara data yang terjadi pada objek penelitian dengan daya yang dapat dilaporkan oleh peneliti. Memperoleh validitas data, peneliti perlu menggunakan teknik triangulasi data. Penelitian tindakan kelas ini, peneliti menggunakan dua macam teknik analisis data, yaitu analisis data kuantitatif dan analisis data kualitatif. Penelitian dilakukan dalam tiga siklus dengan enam pertemuan. Masing-masing siklus melalui 4 tahapan yaitu perencanaan, pelaksanaan, observasi, dan refleksi.

Sebagai dasar untuk menge-tahui keberhasilan penelitian, peneliti menetapkan indikator kinerja pene-litian sebesar $85 \%$ untuk penerapan langkah-langkah pendekatan saintifik dan persentase hasil belajar siswa yang memenuhi KKM=70.

\section{HASIL DAN PEMBAHASAN}

Berdasarkan pelaksanaan tindakan selama tiga siklus dengan enam kali pertemuan, penerapan pendekatan saintifik dengan media konret dalam pembelajaran matematika dilaksanakan dengan langkah-langkah: (1) mengamati, yaitu siswa melihat, mengamati, mendengar, menyimak objek yang disajikan guru, (2) mennanya, yaitu siswa membuat pertanyaan berdasarkan kegiatan mengamati, (3) mencoba, yaitu siswa mencari data untuk menjawab pertanyaan-pertanyaan yang muncul pada kegiatan menanya, (4) menalar, siswa mengaitkan temuan-temuan (data) untuk menghasilkan suatu kesimpulan yang menjawab pertanyaan-pertanyaan yang muncul pada tahap menanya, (5) mengomunikasikan, yaitu siswa menyampaikan kesimpulan yang didapatkan berdasarkan hasil menalar yang bisa dilakukan dalam bentuk lisan dan tertulis.

Penerapan pendekatan saintifik dengan media konkret terhadap pembelajaran Matematika tentang bangun ruang dilaksanakan dalam 3 siklus. Berikut adalah data capaian persentase hasil observasi terhadap guru dan siswa terkait penerapan pendekatan saintifik dengan media konkret pada siklus I, II, dan III: 
Volume 7 Nomor 2 Tahun 2019

Tabel 1 Penerapan Pendekatan Saintifik dengan Media Konkret terhadap Guru dan Siswa

\begin{tabular}{llc}
\hline \multirow{2}{*}{ Siklus } & \multicolumn{2}{l}{ Persentase (\%) } \\
\cline { 2 - 3 } & Guru & Siswa \\
\hline I & 81,18 & 78,95 \\
\hline II & 83,47 & 83,05 \\
\hline III & 88,54 & 88,88
\end{tabular}

Berdasarkan table 1, pembelajaran menggunakan pendekatan saintifik dengan media konkret yang dilaksanakan guru pada siklus I sebesar $81,18 \%$. Rendahnya hasil observasi yang diperoleh pada siklus I dikarenakan ada beberapa deskriptor dari setiap aspek yang belum terpenuhi. Pada siklus II mengalami peningkatan sebesar $2,29 \%$ menjadi $83,47 \%$. Pada siklus III mengalami pe-ningkatan sebesar $5,07 \%$ menjadi $88,54 \%$. Peningkatan yang terjadi pada siklus II dan siklus III terjadi karena telah melakukan perbaikan dan refleksi pada setiap siklusnya. Langkah pembelajaran mengguna-kan pendekatan saintifik dengan media konkret yang dilakukan guru selalu meningkat pada setiap siklusnya.

Berdasarkan Tabel 1 hasil observasi siswa mengalami peningkatan pada setiap tindakan yang dilaksanakan. Rata-rata hasil observasi pembelajaran menggunakan pendekatan saintifik dengan media konkret yang dilaksanakan pada siklus I sebesar $78,95 \%$. Rendahnya hasil observasi yang diperoleh pada siklus I dikarenakan masih banyak deskriptor dari setiap aspek yang belum terpenuhi. Pada siklus II mengalami peningkatan sebesar $4,1 \%$ menjadi $83,05 \%$. Pada siklus III mengalami peningkatan sebesar $5,83 \%$ menjadi $88,88 \%$. Langkah pembelajaran menggunakan pendekatan saintifik dengan media konket yang dilakukan siswa selalu meningkat pada setiap siklusnya. Peningkatan hasil observasi terhadap siswa pada siklus II dan III dikarenakan perbaikan dan refleksi yang dilakukan peneliti

Penelitian juga menggunakan data hasil tes kemampuan memecahkan masalah dalam bentuk hasil belajar siswa. Berikut adalah data nilai hasil belajar pembelajaran Matematika tentang bangun ruang dengan menerapkan pendekatan saintifik dengan media konkret pada siklus I, II, dan III:

Tabel 2 Perbandingan Hasil Belajar pada Siswa, Siklus I, II, dan III

\begin{tabular}{llll}
\hline \multirow{2}{*}{ Tindakan } & $\begin{array}{l}\text { Rata } \\
\text {-rata }\end{array}$ & Persentase (\%) \\
\cline { 3 - 4 } & & Tuntas & $\begin{array}{l}\text { Tidak } \\
\text { Tuntas }\end{array}$ \\
\cline { 3 - 4 } & & & \\
\hline Siklus I & $\begin{array}{l}75,7 \\
6\end{array}$ & 78 & 22 \\
\hline Siklus II & $\begin{array}{l}80,7 \\
2\end{array}$ & 82 & 18 \\
& 2 & & \\
\hline Siklus III & $\begin{array}{l}82,6 \\
4\end{array}$ & 90 & 10 \\
& & & \\
\hline
\end{tabular}


Berdasarkan Tabel 2 dapat dilihat bahwa kemampuan memecahan masalah siswa yang diperoleh melalui tes tertulis mengalami peningkatan. Pada siklus I memperoleh presentase $78 \%$. Pada siklus II mengalami peningkatan sebesar $4 \%$ menjadi $82 \%$. Pada siklus III mengalami peningkatan sebesar $8 \%$ menjadi $90 \%$. Jumlah siswa yang belum tuntas mengalami penurunan pada setiap siklus. Pada siklus I, siswa yang belum tuntas atau belum mencapai KKM $(\geq 70)$ sebesar $22 \%$. Pada siklus II mengalami penurunan sebesar $4 \%$ menjadi $18 \%$. Pada siklus III mengalami penurunan lagi sebesar $8 \%$ menjadi $10 \%$. Penelitian ini juga sejalan dengan penelitian yang dilakukan Titin Budiarti (2014) judul "Peningkatan Aktivitas Peserta Didik Menggunakan Pendekatan Saintifik Di Kelas I Sekolah Dasar Negeri 15" menerangkan bahwa penerapan pendekatan saintifik dalam pembelajaran tematik terpadu dapat meningkatkan aktivitas siswa kelas I SD Negeri 15 Delta Pawan Kabupaten Katapang. Bukti secara kualitatif dapat diketahui dari suasana kelas yang menjadi lebih aktif dan bersemangat. Sedangkan bukti secara kuantitatif dapat dilihat dari aspek aktivitas fisik, mental dan emosional yang meningkat pada setiap siklusnya.

\section{SIMPULAN}

Berdasarkan deskripsi pelaksanaan penelitian selama tiga siklus dalam pembelajaran Matematika pada penelitian tindakan kelas dengan judul Penerapan Pendekatan Saintifik dengan Media Konkret dalam Peningkatan Kemampuan Memecahkan Masalah Siswa Tentang Bangun Ruang Kelas IV SD Negeri 2 Klapasawit Tahun Ajaran 2017/2018 dapat disimpulkan sebagai berikut: (1) Penerapan pendekatan saintifik dengan media konkret tentang bangun ruang dalam peningkatan kemampuan memecahkan masalah siswa tentang bangun ruang kelas IV SD Negeri 2 Klapasawit Tahun Ajaran 2017/2018 dilaksanakan dengan langkah-langkah yaitu: (a) mengamati, (b) menanya, (c) mencoba, (d) menalar, (e) mengkomunikasikan. Langkah pembelajaran oleh guru diukur menggunakan lembar observasi. Pada siklus I sebesar $81,18 \%$, siklus II sebesar $83,47 \%$, dan siklus III sebesar $88,54 \%$. Pembelajaran yang dilaksanakan siswa, yakni siklus I sebesar 78,95\%, siklus II sebesar 83,05\%, dan siklus III sebesar $88,88 \%$.

Penerapan Pendekatan Saintifik dengan media konkret tentang bangun ruang dalam peningkatan kemampuan memecahkan masalah siswa tentang bangun ruang kelas IV SD Negeri 2 Klapasawit Tahun Ajaran 2017/2018, dibuktikan dengan adanya peningkatan kemampuan memecahkan masalah pada tiap siklusnya. Pernyataan tersebut dibuktikan dengan adanya peningkatan ketuntasan hasil belajar siswa setiap siklus, yaitu pada siklus I persentase ketuntasan siswa mencapai $78 \%$, pada siklus II mengalami peningkatan hingga mencapai $82 \%$, pada siklus III ketuntasan hasil belajar siswa telah mencapai $90 \%$ dan sudah mencapai target pada indikator capaian penelitian.

\section{DAFTAR PUSTAKA}

Anitah, S. (2009). Media Pembelajaran. Surakarta: Yuma Pustaka.

Arikunto, S. (2013). Prosedur Penelitian Suatu Pendekatan Praktik. Jakarta: Rineka Cipta.

Asyhar, R. (2011). Kreatif Mengembangkan Media Pembelajaran. Jakarta: Gaung Persada.

Budiarti, T. (2014). Peningkatan Aktivitas Peserta Didik Menggunakan Pendekatan Saintifik Di Kelas I Sekolah Dasar Negeri 15. Diperoleh pada tanggal 23 Januari 2016, dari http://jurnal.untan.ac.id/index.php/jpdpb/article/view/8539.

Daryanto. (2014). Pendekatan Pembelajaran Saintifik Kurikulum 2013. Yogyakarta: Penerbit Gava Media. 
Volume 7 Nomor 2 Tahun 2019

Hosnan, M. (2014). Pendekatan Saintifik dan Kontekstual dalam Pembelajaran Abad 21. Bogor: Ghalia Indonesia.

Mulyasa, E. (2013). Praktik Penelitian Tindakan Kelas. Bandung: Remaja Rosdakarya. Sugiyono. (2009). Metode Penelitian Pendidikan Pendekatan Kuantitatif, Kualitatif, dan $R$ \& $D$. Bandung: Alfabeta. 